University of Wollongong

Research Online

Faculty of Business - Papers (Archive)

Faculty of Business and Law

$1-1-2014$

Does a gender disparity exist in academic rank? Evidence from an Australian university

Arusha Cooray

University of Wollongong, arusha@uow.edu.au

Reetu Verma

University of Wollongong, reetu@uow.edu.au

Lynne Wright

University of Wollongong, Iwright@uow.edu.au

Follow this and additional works at: https://ro.uow.edu.au/buspapers

Part of the Business Commons

Research Online is the open access institutional repository for the University of Wollongong. For further information contact the UOW Library: research-pubs@uow.edu.au 


\title{
Does a gender disparity exist in academic rank? Evidence from an Australian university
}

\begin{abstract}
Employing a unique administrative data set on academics from the University of Wollongong (UOW), we investigate if women are under-represented in academic rank, taking into account information on personal characteristics, job characteristics, education and productivity. The results suggest that males have a significant advantage in rank attainment. The possession of a $\mathrm{PhD}$, the number of years of experience and the number of journal articles, books, book chapters, competitive grants and ERA A* ranked articles appear to be important for academic rank attainment. A Blinder-Oaxaca decomposition test indicates that both supply side and demand side factors play a role; however, there is greater support for the endowments argument. Interviews were conducted in an attempt to explain the results. Interviews showed that men were more career-driven compared to women.
\end{abstract}

\section{Keywords}

disparity, gender, australian, university, evidence, does, rank, academic, exist

Disciplines

Business

\section{Publication Details}

Cooray, A., Verma, R. \& Wright, L. (2014). Does a gender disparity exist in academic rank? Evidence from an Australian university. Applied Economics, 46 (20), 2441-2451. 


\title{
Does a Gender Disparity Exist in Academic Rank? Evidence from an Australian University
}

\author{
Arusha Cooray* \\ School of Economics, University of Wollongong \\ Centre for Applied Macroeconomic Analysis, Australian National University
}

Reetu Verma

School of Economics, University of Wollongong

Lynne Wright

Employment, Equity and Diversity, University of Wollongong

*Corresponding author.

Acknowledgements: We wish to thank two anonymous referees for valuable comments. We also wish to thank, Craig Napier and Matthew Perry for providing us with data, Mei Ball for research assistance, and, Mary Barrett, Anne Collett, Sarah Dolncair, Ben Jann, Amnon Levy, Wenche Ommundsen, and seminar participants at the School of Economics University of Wollongong for insightful suggestions. This project was funded by a University of Wollongong Faculty of Commerce Research Grant. 


\title{
Does a Gender Disparity Exist in Academic Rank? Evidence from an Australian University
}

\begin{abstract}
Employing a unique administrative dataset on academics from the University of Wollongong, we investigate if women are under-represented in academic rank, taking into account information on personal characteristics, job characteristics, education and productivity. The results suggest that males have a significant advantage in rank attainment. The possession of a $\mathrm{PhD}$, the number of years of experience, the number of journal articles, books, book chapters, competitive grants, and ERA $A^{*}$ ranked articles appear to be important for academic rank attainment. A Blinder-Oaxaca decomposition test indicates that both supply side and demand side factors play a role, however, there is greater support for the endowments argument. Interviews were conducted in an attempt to explain the results. Interviews showed that men were more career driven compared to women.
\end{abstract}

Keywords: gender, Australia, academia

JEL Codes: J16 


\section{Introduction}

There has been a growing interest in gender disparity in academic rank in the recent past. Evidence shows a significant difference to exist in academic rank between males and females, particularly at the Professor and Associate Professor levels (Austen 2004, and Mumford 2000 for Australia; Mixon and Trevino 2005 for the US; Ward 2001 for Scotland, and Booth et al. 2000 for the UK). Among the reasons put forward are discrimination (Mixon and Trevino 2005), the lack of role models (Booth et al. 2000), low representation of women on major decision making panels (Carrington and Pratt 2003), career breaks (Castleman et al. 1995), reluctance among women to apply for promotion (Chesterman, Ross-Smith and Peters 2003) and the concentration of women in areas that are less likely to attract funding (White 2003).

Using a unique administrative dataset of 688 academics from the University of Wollongong (UOW), we investigate if women are under-represented in academia at all rank levels (A to E) in total, within individual faculties, and whether the observed gender-based differences in rank attainment can be explained by: (1) differing average personal characteristics, (2) job specific characteristics and/or, (3) differences in productivity. Our study departs from the existing literature in several respects. First, we use a high quality administrative dataset which includes detailed information on staff personal characteristics, job characteristics, education, and productivity (measured by publication output, publication rank and grants successes). Studies undertaken on gender disparity in academic rank hereto, have used primarily survey data, for example, Booth et al. (2000), Blackaby et al. (2005), Ward (2001). Administrative data has the advantage of including large, long and consistent sample sizes of academics' career histories (see Sullivan and von Wachter 2009). We are thus able to avoid problems of bias and low response rates encountered with survey data. Two, our empirical analysis is supplemented by interviews of senior female academics which provide 
further depth to the empirical results absent in quantitative research. The interviews drew attention to particular male attributes which led males to achieve higher rank levels. Finally, our findings have important implications for policy. Identifying if a gender disparity exists in academic rank will help implementing policies to minimize inequalities. The literature at the time of writing this paper indicated that there have been no studies that have addressed the issue of gender disparity among academics in Australia to this level of detail, taking productivity into account ${ }^{1}$.

According to the Equal Opportunity for Women in the Workplace Agency (EOWA 2010, page 2), “An organisation must have a gender inclusive organisational culture that is championed by the CEO, driven by senior executives and holds line managers accountable.” In accordance with this, Universities Australia benchmarks aimed to increase by 2010 women at Level E (Professor) from 16\% in 2004 to 25\%, women at Level D (Associate Professor) from $24 \%$ in 2004 to 35\% and the number of female general staff at Level 10 to 50\% (EOWA 2010). The general consensus is that Australia is still lagging with respect to achieving these benchmarks and that females are over-represented at the lower levels of academic rank (Associate Lecturer and Lecturer) in Australia (Mumford 2000) ${ }^{2}$.

UOW has reviewed its Equal Opportunity Employment (EEO) policies several times and reaffirmed its commitment to continue to support the equal opportunity for women in the workplace. Measures taken by UOW to support gender equality in academic appointment are: career development planning, management training and leadership training programmes for women, conducting annual meetings between Deans, Directors and the Director of Employment, Equity and Diversity (EED) to discuss equity strategies concerning the promotion of women, supporting women in the completion of $\mathrm{PhDs}$ and identifying opportunities for women to gain promotion. Despite the

\footnotetext{
${ }^{1}$ There is a literature which examines the gender salary gap. Our study however, focuses on the gender gap in academic rank.

${ }^{2}$ Mumford (2000) finds that of the sample of countries investigated, Australia has the largest relative proportion of females at lower ranks levels.
} 
measures taken, UOW remains behind the Universities Australia 2010 benchmarks for women with employment of $16.7 \%$ for level E (benchmark 25\%), and $28.7 \%$ for women at Level D (benchmark 35\%) as at 2010. The benchmark for female general staff to 50\% by 2010 has been achieved (EOWA 2010).

Our ordered probit results suggest that the reasons for the gender disparity in academia are due to supply side factors such as productivity, experience and qualification. A Blinder-Oaxaca decomposition test indicates that both male and female endowments (supply side) and discrimination (demand side) may play a role, however, there is greater support for the endowments argument. The interviews confirm that these supply side factors arise mainly due to differing characteristics of males compared to females. Interviewees were of the view that males are in general more career driven compared to females.

The rest of this paper is structured as follows. Section 2 briefly reviews the literature. Section 3 describes the data and methodology. Section 4 evaluates the empirical results and discusses possible reasons for results through interviews and Section 5 provides the concluding remarks.

\section{Literature Review}

Much of the literature on gender discrepancies in academic rank attribute this inequality to demand side factors, primarily discrimination - see for example the studies of McDowell et al. (1999), Mixon and Trevino (2005), Winter-Ebmer and Zweimuller (1997), Ginther and Hayes (1999). On the demand side, Mumford (2000) observes the lack of intermediate level vacancies for females, which prevents females from moving to intermediate and thus senior positions. Studies which attribute the gender discrepancy in academic rank to both demand and supply side factors include those of Booth et al. (2000), Austen (2004) and Ward (2001). 
Employing data from the Austrian micro-census, Winter-Ebmer and Zweimuller (1997) investigate gender differentials in the professional status attainment of women. They find evidence of discrimination with females restricted to lower hierarchical positions and need to satisfy greater standards to be promoted. McDowell et al. (1999) similarly, examining gender differences in promotion opportunities among academic economists using panel data observations from the American Economic Association (AEA), find evidence of discrimination between men and women even with controls for gender differences in productivity. They also find that as the level of education rises, females find it harder to attain higher ranks. Similar conclusions are drawn by Mixon and Trevino (2005), who employ web based data to examine the probability of an US economic academic holding a named professorship. They find evidence of gender discrimination in the named professorship process at US higher education institutions. Utilizing data from waves of the Survey of Doctorate Recipients, Ginther and Hayes (1999) find significant differences in promotion to tenure by gender after controlling for productivity, demographic characteristics, and discipline. Mumford (2000) in a study of the positions of males and females in economics in Australia, finds that females are concentrated at junior levels. Despite this strong concentration of females at junior levels, there is an absence of females at intermediate and senior levels. She however, attributes this to the lack of intermediate level job availability for females rather than discrimination. This however is speculative and not empirically tested by Mumford. Everett (1994) using surveys of the demographics of academic staff at four Australian universities in1978/9, 1984 and 1990, concludes that there are significant gender differences in rank attainment at each of the four universities not explained by endowment. These discrepancies in rank moreover, have not diminished significantly between 1978/9 and1990, despite the increased participation of females in the academic workforce in this 
period. Everett however, concludes that although the evidence is consistent with discrimination, it does not necessarily prove discrimination.

The studies of Booth et al. (2000), Austen (2004) and Ward (2001), attribute the gender discrepancy in academic rank to both demand and supply side factors. Investigating the position of female academics in economics in the UK, Booth et al. (2000) find evidence of male domination of the profession. They observe an increase in females from fixed term lectureships rather than permanent lectureships. They note that supply side factors include low levels of female interest in economics, the mathematical nature of the subject, and lack of role models, and demand-side factors, discrimination in appointments and promotions. They also find that the proportion of female students increases significantly with the proportion of female staff, which they attribute to a role model effect. The study of Ward (2001) uses survey data on personal and work history, productivity and salary of 900 academics from five established universities in Scotland to investigate factors influencing academic rank attainment and promotion. Despite controlling for personal attributes, Ward concludes that women are underrepresented within the senior ranks of academia and women are less likely to be promoted at each rung of the job ladder. Ward (2001) attributes this to both demand and supply side factors. Austen (2004) also finds similar evidence for Australia. Using information on staff compiled by the Federal Department of Employment, Science and Training (DEST) on staff employment in Australian universities, Austen finds that there are significant differences in between males and females in that they will be employed in one of the top two academic grades. 
These differences are shown to persist even after taking into account differences in age, qualifications, discipline area and institution characteristics which she attributes to both demand and supply side factors.

Diezmann and Grieshaber (2010), examine gender equality by cohort at the professorial rank level. Based on over 500 survey responses, they find similarities between males and females appointed to the professor and associate professor level between 2005 and 2008 . Males and females appointed through internal, external processes or by invitation were similar in proportion. Similar proportions of women and men professors stated a preference for research over teaching. Additionally, there was similarity in the distributions between males and females in the age of appointment to the rank of professor. A significant gender difference however, existed in the appointment of a female to the rank of professor which was on average 1.9 years later compared to males. Booth et al. (2000) argue that the low female proportion at higher levels could reflect to some degree a cohort effect. As many women have left academic economics by this stage, senior levels are dominated by males. Blackaby et al. (2005) find evidence of differential mobility of male and female academics in Britain with men receiving more outside offers compared to females with similar characteristics.

The majority of the literature on academic rank differentials employ survey data which are subject to problems of bias. We overcome the shortcomings encountered by survey data by employing a quality administrative dataset. Additionally, the Australian studies are mainly descriptive, and do not involve any empirical analysis. Therefore, our study improves upon the Australian literature in that we investigate empirically if any gender disparity exists in academic rank. Another point of departure from the literature is in the use of interviews to supplement our empirical results. The interviews provide support for the supply side endowments argument, however, from a deeper psychological perspective, by identifying 
particular male attributes as consistent with their endowments which permit them to achieve higher rank levels.

\section{Data and Methodology}

\subsection{Data}

Data for 688 staff members employed at UOW are obtained from the Research Information System (RIS), Research Online System (ROS) and Performance Indicators. The data covered information on staff members (i) Personal characteristics which included gender; (ii) Job characteristics - whether an employee was full time or part time, faculty the academic was employed in, the employee's current rank (A-E) and number of years at UOW; (iii) education - whether an employee held a PhD or not; (iv) Productivity - the total number of articles published, the total number of authored books and book chapters and the number of conference proceedings. The number of refereed journal articles were then classified by A*, A, B, C according the Excellence in Research for Australia (ERA) rankings, and the number of grants received were classified according to competitive or otherwise over the 2000-2010 period $^{3}$. Ideally we should also have included wages in our analysis, this data however, were not available. Table 1 provides a summary of the variables used in the study.

[Table 1, about here]

Tables 2 and 3 present a comparative percentage distribution of academics by gender in rank attainment at UOW as a whole, and disaggregated by each of the eleven faculties. Table 2 indicates that there are $61.4 \%$ male academics compared to $38.6 \%$ female academics at

\footnotetext{
${ }^{3}$ The Excellence in Research for Australia (ERA) initiative assesses research quality within Australia's higher education institutions using a combination of indicators (Australia Research Council 2011 http://www.arc.gov.au/era/). Since the total number of publications (including journal articles, books, book chapters, conference papers) and receipt of funding is misleading for publications/funding, where there are more than one author, we weight the number of publications/receipt of funding by the number of co-authors in the empirical estimation so that it accurately reflects productivity.
} 
UOW. It is interesting to note that as academic rank increases, proportionately more males have reached higher academic ranks, while the converse is true for females. Overall at UOW within the male cohort, the largest group are senior lecturers (29\%), followed by lecturers (25\%), associate professors (23\%), professors (22\%) and associate lecturers (1\%). On the other hand, within the female cohort, the largest group are lecturers (45\%), followed by senior lecturers (26\%), associate professors (15\%) and professors and associate lecturers at 7\% each. Almost half the female cohort comprises lecturers. The percentage of males and females by faculty reported in Table 3, shows that the percentage of females are higher in the faculties of Arts, Creative Arts, Education, Health Sciences and the Graduate School of Medicine (GSM). In the rest of the faculties there are a higher proportion of males compared to females with the disparity greater in Commerce, Engineering, Informatics and Science.

[Tables 2-3, about here]

In order to see if this difference in rank attainment is due to difference in research output, Table 4 presents the distribution of research output for the $2000-2010$ period. The total number of journal articles are higher for males at all levels with the exception of the associate lecturer level. A similar trend is observed for total conference proceedings and book chapters. However, journal articles per capita are higher for females at the senior lecturer and professor levels despite the lower number of females employed at these levels. Similarly, the number of conference proceedings per capita is higher for females at the senior lecturer and professor levels. Book and book chapters is also higher for females at the professor level compared to males and equal with males at the senior lecture level.

An examination of research output by faculties in Table 5 shows that the number of journal articles are higher for males in all faculties with the exception of Education and GSM. The number of conference proceedings is also higher for males in all faculties with the 
exception of Education, Health Sciences and the GSM and book chapters in Creative Arts, Education and the GSM.

[Tables 4-5, about here]

This gives rise to the question of whether gender productivity differences are the reason for the gender rank gap.

\subsection{Methodology}

The paper conducts and an ordered probit model to identify the probability of individual i being in a particular rank on the basis of an underlying latent variable, $\mathrm{r}^{*}$, which is a linear function of a vector of explanatory variables, $\mathrm{z}$, and its relationship to the threshold parameters, $\mu . \varepsilon$ is a random error term. We can express this as follows:

$$
r_{i}^{*}=\beta z_{i}+\varepsilon_{i}
$$

r* is unobserved, what we do observe is (see Greene 2003),

$$
\begin{array}{ll}
y=1 & \text { if } \mu_{0} \leq r^{*} \prec \mu_{1} \\
y=2 & \text { if } \mu_{1} \leq r^{*} \prec \mu_{2} \\
y=3 & \text { if } \mu_{2} \leq r^{*} \prec \mu_{3} \\
y=4 & \text { if } \mu_{3} \leq r^{*} \prec \mu_{4} \\
y=5 & \text { if } \mu_{4} \leq r^{*}
\end{array}
$$

Where $r$ is academic rank, which takes on a value of 1 for associate lecturers, 2 for lectures, 3 for senior lectures, 4 for associate professors and 5 for professors. $\mu$ denotes a set of threshold parameters that will be estimated with $\beta$. The explanatory variables include gender which takes on a value of 1 for male and 0 otherwise, whether academic is full time, faculty the academic is employed in, number of years at UOW, and whether an employee holds a PhD. Productivity is measured by taking into account not only the quantity of publications, but also the quality of publications. Quantity is measured by the number of journal articles, authored books and book chapters, number of conference proceedings, number of competitive grants and other grants. The quality of research output is measured by 
taking into account the ERA ranking of journal articles and distinguishing between competitive and other research grants (see Table 1). The number of years in employment also enters the estimation in quadratic form in order to account for any non-linearity in experience.

The Blinder (1973) and Oaxaca (1973) counterfactual decomposition method is used to investigate mean outcome differences between groups (see Jann 2008) ${ }^{4}$. Blinder (1973) and Oaxaca (1973) divide the rank differential between groups into a component that is explained by group differences (endowments) and a component that cannot be explained by these differences which is also called a measure of discrimination ${ }^{5}$. If the average rank of males and females respectively were given by, $\overline{r_{m}}$ and $\overline{r_{f}}$, the average characteristics of males and females by $\overline{Z_{m}}$ and $\overline{Z_{f}}$ and the gender specific coefficients (including the intercept) for males and females by $\hat{\beta}_{m}$ and $\hat{\beta}_{f}$, $\overline{r_{m}}=\overline{Z_{m}} \hat{\beta}_{m}$ and $\overline{r_{f}}=\overline{Z_{f}} \hat{\beta}_{f}$

The gender difference in average rank, $\overline{r_{m}}-\overline{r_{f}}$, can be expressed:

$\overline{r_{m}}-\overline{r_{f}}=\left(\bar{Z}_{m}-\bar{Z}_{f}\right) \hat{\beta}_{m}+\left(\hat{\beta}_{m}-\hat{\beta}_{f}\right) \bar{Z}_{f}$

where the first term on the right hand side in the above equality captures the effect on the gender rank gap of differences in the average characteristics of men and women, $\bar{Z}_{m}-\bar{Z}_{f}$, evaluated at the male coefficients $\hat{\beta}_{m}$, and the second term (the unexplained component), captures discrimination. We use the Blinder-Oaxaca (1973) method to see the degree to which the gender gap in academic rank is explained by endowments and discrimination.

\footnotetext{
${ }^{4}$ The Blinder-Oaxaca method is used for example by Broder (1993) to investigate gender differences in remuneration and professional achievement among academic economists, by Warman et al. (2010) to investigate male and female earnings differences in Canadian Universities.

${ }^{5}$ Note that this term could also incorporate effects of group differences in unobserved variables (Jann 2008).
} 


\section{Empirical Results}

Table 6 presents coefficient estimates for the ordered probit regressions. Initial estimation is carried out on the full sample for 2000-2010, see column (1). Estimation is also carried out by splitting the sample into two sample periods, 2000-2005 (column 2) and 2006-2010 (column 3) as many academics pointed out that gender difference in academia might have decreased in the 2006-2010 period.

[Tables 6-7, about here]

In Table 6, the results for all three time periods indicate that the coefficient on male is positive and significant suggesting that males have a strong advantage in rank attainment. Similarly, holding a $\mathrm{PhD}$, and the number of years in service are significant for rank attainment. While being a full time employee is significant at the $10 \%$ level in the full sample, it is not statistically significant in the two sub-periods individually. Taking the full sample period, those in Creative Arts, Education, Health Science, Law and the GSM have a greater probability of attaining a higher rank relative to those in the base category, Arts. In the sub-samples, those in Commerce, Engineering, Health Science Law and GSM in 20002005, and academics in Commerce, Engineering, Health Science, Law, GSM, the Sydney Business School, Science and Informatics in 2006-2010 are more likely to attain a higher rank compared to those in Arts in these time periods. An examination of the productivity variables indicate that the number of journal articles, book and book chapters and competitive grants are positive and statistically significant at the $5 \%$ level for all three periods suggesting that journal publications, book and book chapters and competitive grants are important for the attainment of academic rank at UOW. 
Table 7 presents marginal probabilities implied by the ordered probit estimates for the full sample ${ }^{6}$. The highest base probability attached to the senior lecturer level, reflects that the highest percentage of academics are at this level. The estimates on gender suggest that the gender effect is particularly significant at the associate and lecturer levels, placing females at these ranks in a position of disadvantage. Conversely males are at an advantage at the associate professor and professor levels. Similarly the negatively signed coefficients on the productivity variables indicate that those at the associate lecturer and lecturer levels are less likely to achieve better outcomes in terms of academic output and therefore academic rank. The estimates for the faculties suggest that academics in all faculties find it more difficult to achieve higher ranks levels from the associate lecturer to senior lecturer levels compared to those in the Arts faculty.

\section{Robustness Tests}

Several checks have been performed to ensure the robustness of the results. A number of variables controlling for academic personal characteristics, job characteristics, employment and productivity were included in the initial estimation to ensure the robustness of the results to the inclusion of these variables (see Tables 6-7). We in addition, split the full sample into two sub-periods 2000-2005 and 2006-2010, to check if gender differentials have decreased over time. However, the results presented in Table 6 suggest that gender differentials have not diminished over time and that the coefficient on male remains positive and significant across both time periods. Splitting the sample this way and estimating the model corrects for any endogeneity bias that may be present in the model. Although past productivity can affect current outcomes (rank attainment), and current rank attainment may affect current productivity, current outcomes cannot affect past productivity. In other words, rank

\footnotetext{
${ }^{6}$ Marginal probabilities computed for all regressions, however, not reported due to space constraints.
} 
attainment in 2010 could not have influenced productivity in 2000-2005, eliminating any issues concerning endogeneity.

Next, we control for the quality of research output by replacing the variable for total number of journal articles by the number of ERA ranked and ERA unranked (other) journal articles. The results are presented in Tables 8 . As before, the estimation is carried out on the full sample 2000-2010 and the two sub-samples, 2000-2005 and 2006-2010.

[Table 8, about here]

The results for all three time periods once again, indicate that the coefficient on male is positive and significant suggesting that males have a significant advantage in rank attainment, consistent with the results obtained in Tables 6-7. The overall estimates for the other job and education related variables are also similar to those in Table 6. Holding a PhD, and the number of years in service are also significant for rank attainment. Being a full time employee is significant at the $10 \%$ level in the full sample, but is not statistically significant in the two sub-periods individually. Taking the full sample period, those in Creative Arts, Education, Health Science, Law and the GSM have a greater probability of attaining a higher rank relative to those in the base category, Arts. In the sub-samples 2000-2005 and 20062010, those in Commerce, Engineering, Health Science Law, GSM and the Sydney Business School in 2006-2010 are more likely to attain a higher rank compared to those in Arts. An examination of the coefficients on the ERA ranked journal article variables indicate that the coefficients on $A^{*}$ journal publications are positive and statistically significant for all three time periods. Surprisingly the coefficients on A and B ranked journal articles and other unranked journal articles are statistically significant only for the sub-period 2000-2005, while C ranked journal articles are significant for the full sample and the 2006-2010 period. Books and book chapters and competitive grants are also statistically significant across all three time 
periods. However, conference proceedings are only significant for the earlier (2000-2005) period, while non-competitive grants are only significant for the 2006-2010 period; but both significant only at the $10 \%$ level.

[Table 9, about here]

Next we use the Blinder-Oaxaca decomposition (Blinder 1973, Oaxaca 1973) which divides the rank differential between two groups into a part that is "explained” by group differences in personal, productivity and jobs specific characteristics and a residual part that cannot be accounted for by differences in rank determinants. This "unexplained” part is often used as a measure of discrimination, but it can also include the effects of group differences in unobserved predictors (Jann 2008). Table 9 reports the results of the Oaxaca-Blinder decomposition. The rank differential between males and females is divided into a part that is explained by differences in determinants of rank including qualification, number of years of experience, whether full time or part time, productivity (measured by journal rank A*, A, B, C, other, number of conferences, number of book and book chapters, number of competitive grants and number of other grants) and a part that is not explained by group differences. The predicated female coefficient with male endowments (in columns 2 and 3) shows that differences in endowments account for $59 \%$ of the rank differential. The second term which denotes the change in the rank of women when applying the male coefficients to the female characteristics accounts for $41 \%$ suggesting some evidence of discrimination. The negative coefficients on the endowments and coefficients in column (4) suggest that men are worse off with female endowments and coefficients. The predicated male coefficient with female endowments (in column 5) shows that differences in endowments account for $65 \%$ of the rank differential and the change in the rank of men when applying the female coefficients to the male characteristics accounts for $35 \%$. 


\section{Interviews}

Informal face to face interviews were held with female academics at UOW at senior positions, in order to gain further insight into gender disparity in academic rank. Apart from the obvious reason of females taking one or more career breaks to have and raise children, there was a general consensus on why there is a lower probability for females to be employed in higher ranks compared to males. Interviewees felt that a larger proportion of male academics applied for promotion compared to their female counterparts. Interviewees also believed that males were higher risk takers in that they applied for promotion even if they were not certain of gaining it. Female academics on the contrary, applied for promotion only when they were fairly certain they would gain promotion ${ }^{7}$. Many interviewees agreed that female academics were more inclined to say 'yes' to taking on administrative roles and in general had higher teaching loads compared to males. Men on the other hand, chose their administrative roles and teaching tasks more strategically. Some also felt that women devoted more time to preparing lecture notes compared to men, leaving less time for research. Interviewees were of the view that men attended more conferences and were better at networking at conferences compared to females. Interviewees also believed that schools in which females held senior positions, there was greater mentoring of staff at junior levels. Overall, the interviews provided greater support for the supply side endowments argument, however, from a from a deeper psychological perspective, by identifying particular male attributes which permitted them to attain higher rank levels compared to females.

\section{Conclusion}

This study investigates if women are under-represented in academic rank and the reasons for any discrepancy in academic rank attainment at UOW. The empirical results indicate that

\footnotetext{
${ }^{7}$ The argument that females are more risk averse is also supported by Blackaby et al. (2005).
} 
males have a significant advantage in rank attainment consistent with previous studies. The possession of a $\mathrm{PhD}$, the number of years of experience, the number of journal articles, books, book chapters, competitive grants, and ERA A* ranked articles appear to be important for academic rank attainment at UOW. Lastly, the results from a Blinder-Oaxaca decomposition test indicates that both supply side and demand side factors play a role; however, there is greater support for the endowments argument. A limitation of our study is the inability to capture teaching and administrative loads. The study is additionally limited to one university, UOW.

These results suggest that UOW should take measures to support women in the completion of PhDs, improve resources, systems and practices that permit women to produce better quality research outputs in the form of journal articles, books and book chapters, and provide institutional support for women to apply for competitive research grants. Taking into account the responses of the interviewees, mentorship and staff development that promotes academic activities such as collaboration and dissemination of work should be further investigated for promotion and retention of female staff. 


\section{References}

Austen, S. (2004), 'Gender Differences in Academic Rank in Australian Universities', Australian Bulletin of Labour, 30, 113-133.

Australia Research Council (2011) 'The Excellence in Research for Australia (ERA) Initiative', http://www.arc.gov.au/era/

Blackaby, D., Booth, A. and Frank, J. (2005), 'Outside Offers and the Gender Pay Gap: Empirical Evidence from the UK Academic Labor Market', Economic Journal, 115 (501), F81-107.

Blinder, A. (1973), 'Wage Discrimination: Reduced Form and Structural Estimates', Journal of Human Resources, 8, 436-455.

Booth, A., Burton, J., and Mumford, K. (2000), 'The Position of Women in UK Academic Economics', The Economic Journal, 110(464), F312-F333. http://www.jstor.org/stable/2566131 Accessed: 21/06/2012 22:41

Broder I (1993) Professional Achievements and Gender Differences Among Academic Economists, Economic Inquiry, 31, 116-127.

Carrington, K. and Pratt, A. (2003), 'How Far Have We Come? Gender Disparities in the Australian Higher Education System', Current Issues Brief No. 31, Information and Research Services, Department of Parliamentary Library.

Castleman, T., Allen, M., Bastalich, W. and Wright, P. (1995), 'Limited Access: Women’s Disadvantage in Higher Education Employment', National Tertiary Education Union.

Chesterman, T., Ross-Smith, A and M. Peter (2003), 'Senior Women Executives and the Cultures of Management', A Report to ATN Universities, University of Technology, Sydney.

Diezmann, C. and Grieshaber, S. (2010), 'Gender Equity in the Professoriate: A Cohort Study of New Women Professors in Australia', Paper presented at the 33rd HERDSA Annual International Conference, 6-9 July, 223-234. Melbourne, Australia.

Everett, J. (1994), 'Sex, Rank and Qualifications at Australian Universities', Australian Journal of Management, 19, 159-175

Equal Opportunity for Women in the Workplace Agency (2010), EOWA Employer Choice for Women, EOCFW.

Ginther, D. and Hayes, K. (1999), 'Gender Differences in Salary and Promotion in the Humanities', The American Economic Review, 89(2), 397-402. Papers and 
Proceedings of the One Hundred Eleventh Annual Meeting of the American Economic Association.

http://www.jstor.org/stable/117143 Accessed: 26/06/2012 19:11.

Greene, W. (2003), Econometric Analysis, Pearson Education International, New York.

Jann, B. (2008), ‘The Blinder-Oaxaca Decomposition for Linear Regression Models’, The

Stata Journal, 8(4), 453-479

Jones, D. and Makepeace, H, (1996), 'Equal Worth, Equal Opportunities: Pay and Promotion in an Internal Labour Market', The Economic Journal, 106(435), 401-409. http://www.jstor.org/stable/2235255 Accessed: 26/06/2012 19:21

Kahn, S. (1993), 'Gender Differences in Academic Career Paths of Economists', The American Economic Review, 83(2), 52-56. Papers and Proceedings of the Hundred and Fifth Annual Meeting of the American Economic Association. http://www.jstor.org/stable/2117639 Accessed: 26/06/2012 19:22.

McDowell, J., Singell, L., and Ziliak, J. (1999), 'Cracks in the Glass Ceiling: Gender and Promotion in the Economics Profession', The American Economic Review, 89(2), Papers and Proceedings of the One Hundred Eleventh Annual Meeting of the American Economic Association.

http://www.jstor.org/stable/117142 Accessed: 26/06/2012 19:24.

Mixon, F. and Trevino, L. (2005), 'Is There Gender Discrimination in Named Professorships? An Econometric Analysis of Economics Departments in the US South', Applied Economics, 37(8), 849-854.

Mumford, K. (2000), 'The Relative Positions of Men and Women in Australian Academic Economics’, Economic Papers, 19(1), 18-27.

Oaxaca, R. (1973), ‘Male-Female Wage Differentials in Urban Labor Markets’, International Economic Review, 14, 693-709.

Sullivan, D. and von Wachter, T. (2009), 'Job Displacement and Mortality: An Analysis Using Administrative Data', Quarterly Journal of Economics, 124(3), 1265-1306.

Ward, M. (2001a), 'The Gender Salary Gap in British Academia', Applied Economics, 33, 1669-1681.

Ward, M. (2001b) 'Gender and Promotion in the Academic Profession,' Scottish Journal of Political Economy, 48, 283-302.

Warman C, Woolley F and Worswick C (2010) The Evolution of Male and Female Earnings Differentials in Canadian Universities, 1970-2001, Canadian Journal of Economics, 48, 347-382. 
Watts, M. and Rich, J. (1992), 'Labour Market Segmentation and the Persistence of Occupational Sex Segregation in Australia’, Australian Economic Papers, 31(58), 5876.

White, K. (2003), 'Women and leadership in higher education in Australia. Tertiary Education and Management, 9, 45-60.

Winter-Ebmer, R. and Zweimüller, J. (1997), 'Unequal Assignment and Unequal Promotion in Job Ladders', Journal of Labor Economics, 15(1), 43-71. http://www.jstor.org/stable/2535314 Accessed: 26/06/2012 19:25. 
Table 1: Description of Variables

\begin{tabular}{|c|c|}
\hline Variable & Description \\
\hline Rank & $\begin{array}{l}=1 \text { if Associate Lecturer } \\
=2 \text { if Lecturer } \\
=3 \text { if Senior Lecturer } \\
=4 \text { if Associate Professor } \\
=5 \text { if Professor }\end{array}$ \\
\hline \multicolumn{2}{|l|}{ Personal Characteristics: } \\
\hline Gender & $1=$ Male, $0=$ Female \\
\hline \multicolumn{2}{|l|}{ Job Characteristics: } \\
\hline Faculty & $\begin{array}{l}=1 \text { if Arts, } 0 \text { otherwise } \\
=1 \text { if Commerce, } 0 \text { otherwise } \\
=1 \text { if Creative Arts, } 0 \text { otherwise } \\
=1 \text { if Education, } 0 \text { otherwise } \\
=1 \text { if Engineering, } 0 \text { otherwise } \\
=1 \text { if Health Science, } 0 \text { otherwise } \\
=1 \text { if Informatics, } 0 \text { otherwise } \\
=1 \text { if Law, } 0 \text { otherwise } \\
=1 \text { if Science, } 0 \text { otherwise } \\
=1 \text { if Graduate School of Medicine, } 0 \\
\text { otherwise } \\
=1 \text { if Sydney Business School, } 0 \\
\text { otherwise }\end{array}$ \\
\hline Employment & $=1$ if full time employee, 0 otherwise \\
\hline Year & Number of Years at UOW \\
\hline Education & $=1$ if holds $\mathrm{PhD}, 0$ otherwise \\
\hline \multicolumn{2}{|l|}{ Productivity: } \\
\hline Journal Articles & $\begin{array}{l}\text { Total Number of Journal Articles } \\
\text { Published }\end{array}$ \\
\hline Books & $\begin{array}{l}\text { Number of Published Books and } \\
\text { Book Chapters }\end{array}$ \\
\hline Conference Proceedings & Number of Conference Proceedings \\
\hline A* Journal Articles & $\begin{array}{l}\text { Number of ERA A*Ranked Journal } \\
\text { Articles }\end{array}$ \\
\hline A Journal Articles & $\begin{array}{l}\text { Number of ERA A Ranked Journal } \\
\text { Articles }\end{array}$ \\
\hline B Journal Articles & $\begin{array}{l}\text { Number of ERA B Ranked Journal } \\
\text { Articles }\end{array}$ \\
\hline C Journal Articles & $\begin{array}{l}\text { Number of ERA C Ranked Journal } \\
\text { Articles }\end{array}$ \\
\hline Other Journal Articles & $\begin{array}{l}\text { Number of ERA Unranked Journal } \\
\text { Articles }\end{array}$ \\
\hline Competitive Grants & $\begin{array}{l}\text { Number of Competitive Grants } \\
\text { Received }\end{array}$ \\
\hline Other Grants & $\begin{array}{l}\text { Other Grants not Ranked as } \\
\text { Competitive Grants }\end{array}$ \\
\hline
\end{tabular}


Table 2: Percentage of Males and Females by Academic Rank as of 2010

\begin{tabular}{lrr}
\hline Rank & $\begin{array}{c}\text { Males } \\
\text { \% of total in } \\
\text { rank }\end{array}$ & $\begin{array}{c}\text { Females } \\
\text { \% of total in } \\
\text { rank }\end{array}$ \\
\hline Associate Lecturer & & \\
\hline Lecturer & 25.0 & 75.0 \\
\hline Senior Lecturer & 47.3 & 52.7 \\
\hline Associate Professor & 63.0 & 37.0 \\
\hline Professor & 71.3 & 28.7 \\
\hline Total & 83.3 & 16.7 \\
\hline
\end{tabular}

Table 3: Percentage of Males and Females by Faculty as of 2010

Faculty \% of total Male \% of total Female

\begin{tabular}{lrr}
\hline Arts & 8.1 & 12.5 \\
\hline Commerce & 16.2 & 12.5 \\
\hline Creative Arts & 5.0 & 6.8 \\
\hline Education & 3.8 & 14.7 \\
\hline Engineering & 13.8 & 1.1 \\
\hline Health Sciences & 9.5 & 19.6 \\
\hline Informatics & 16.9 & 9.8 \\
\hline Law & 5.9 & 4.5 \\
\hline Science & 12.4 & 9.4 \\
\hline Graduate School of & & \\
Medicine & 5.7 & 8.3 \\
\hline Sydney Business School & 2.9 & 0.8 \\
\hline Total & 100.0 & 100.0 \\
\hline
\end{tabular}


Table 4: Distribution of Research Output by Rank and Gender

\begin{tabular}{|c|c|c|c|c|c|c|c|c|c|c|c|c|}
\hline & \multicolumn{6}{|c|}{ Male } & \multicolumn{6}{|c|}{ Female } \\
\hline Rank & $\begin{array}{l}\text { Journal } \\
\text { Articles }\end{array}$ & $\begin{array}{c}\text { Journal } \\
\text { articles } \\
\text { per } \\
\text { capita } \\
\end{array}$ & $\begin{array}{l}\text { Conference } \\
\text { proc. }\end{array}$ & $\begin{array}{c}\text { conference } \\
\text { proc. per } \\
\text { capita }\end{array}$ & $\begin{array}{c}\text { Books/ } \\
\text { Book } \\
\text { Chapters }\end{array}$ & $\begin{array}{l}\text { Books } \\
\text { per } \\
\text { Capita }\end{array}$ & $\begin{array}{l}\text { Journal } \\
\text { Articles }\end{array}$ & $\begin{array}{c}\text { Journal } \\
\text { articles per } \\
\text { capita }\end{array}$ & $\begin{array}{l}\text { Conference } \\
\text { proc. }\end{array}$ & $\begin{array}{l}\text { conference } \\
\text { proc. per } \\
\text { capita }\end{array}$ & $\begin{array}{c}\text { Books/ Book } \\
\text { Chapters }\end{array}$ & $\begin{array}{l}\text { Books } \\
\text { per } \\
\text { Capita }\end{array}$ \\
\hline $\begin{array}{l}\text { Associate } \\
\text { Lecturer }\end{array}$ & 10 & 1.7 & 7 & 1.2 & 0 & 0.0 & 14 & 0.8 & 16 & 0.9 & 2 & 0.1 \\
\hline Lecturer & 566 & 5.3 & 274 & 2.6 & 33 & 0.3 & 294 & 2.5 & 173 & 1.5 & 26 & $\overline{0.2}$ \\
\hline Senior Lecturer & 1207 & 10.0 & 342 & 2.8 & 84 & 0.7 & 786 & 11.1 & 282 & 4.0 & 53 & 0.7 \\
\hline $\begin{array}{l}\text { Associate } \\
\text { Professor }\end{array}$ & 2541 & 26.2 & 501 & 5.2 & 155 & 1.6 & 573 & 14.7 & 218 & 5.6 & 69 & 1.8 \\
\hline Professor & 3873 & 43.0 & 435 & 4.8 & 135 & 1.5 & 811 & 45.1 & 188 & 10.4 & 71 & 3.9 \\
\hline
\end{tabular}

Note: The number of journal articles, conference proceedings and book and book chapters are for the period 2000-2010 and per capita outputs for 2010 .

Table 5: Distribution of Academics by Faculty

\begin{tabular}{l|rrr|rrr}
\hline FACULTY & \multicolumn{3}{|c|}{ MALE } & \multicolumn{3}{c}{ FEMALE } \\
\hline & $\begin{array}{c}\text { Journal } \\
\text { Articles }\end{array}$ & $\begin{array}{c}\text { Conference } \\
\text { proc. }\end{array}$ & $\begin{array}{r}\text { Books/ } \\
\text { Book } \\
\text { Chapters }\end{array}$ & $\begin{array}{c}\text { Journal } \\
\text { Articles }\end{array}$ & $\begin{array}{c}\text { Conference } \\
\text { proc. }\end{array}$ & $\begin{array}{c}\text { Books/ } \\
\text { Book } \\
\text { Chapters }\end{array}$ \\
\hline Arts & 444 & 47 & 119 & 160 & 35 & 92 \\
\hline Commerce & 594 & 356 & 56 & 278 & 219 & 39 \\
\hline Creative Arts & 122 & 40 & 8 & 49 & 13 & 10 \\
\hline Education & 168 & 82 & 32 & 191 & 120 & 46 \\
\hline Engineering & 3024 & 389 & 16 & 266 & 12 & 0 \\
\hline Health Sciences & 1123 & 199 & 38 & 754 & 291 & 13 \\
\hline Informatics & 646 & 329 & 39 & 306 & 118 & 9 \\
\hline Law & 197 & 30 & 55 & 44 & 27 & 2 \\
\hline Science & 1775 & 47 & 40 & 323 & 14 & 9 \\
\hline Graduate Sch of Medicine & 81 & 12 & 0 & 103 & 25 & 1 \\
\hline Sydney Business School & 23 & 28 & 4 & 4 & 3 & 0 \\
\hline Total & 8197 & 1559 & 407 & 2478 & 877 & 221
\end{tabular}

Note: The number of journal articles, conference proceedings and book and book chapters are for the period 2000-2010. 
Table 6: Ordered Probit Coefficient Estimates

Dependent Variable Rank (Y=1, 2, 3, 4, 5)

\begin{tabular}{|c|c|c|c|}
\hline & (1) & (2) & (3) \\
\hline Independent Variables & $2000-2010$ & $2000-2005$ & 2006-2010 \\
\hline \multirow[t]{2}{*}{ Variable } & Coefficient & Coefficient & Coefficient \\
\hline & Estimate & Estimate & Estimate \\
\hline \multirow[t]{2}{*}{ Male } & 0.429 & 0.405 & 0.416 \\
\hline & $(0.097)^{* * *}$ & $(0.096)^{* * *}$ & $(0.096)^{* * *}$ \\
\hline \multirow[t]{2}{*}{ Full Time } & 0.259 & 0.220 & 0.217 \\
\hline & $(0.141)^{*}$ & $(0.140)$ & $(0.138)$ \\
\hline \multirow[t]{2}{*}{$\mathrm{PhD}$} & 1.440 & 1.489 & 1.431 \\
\hline & $(0.143)^{* * *}$ & $(0.142)^{* * *}$ & $(0.144)^{* * *}$ \\
\hline \multirow[t]{2}{*}{ Years } & 0.046 & 0.044 & 0.049 \\
\hline & $(0.014)^{* * *}$ & $(0.014)^{* * *}$ & $(0.014)^{* * *}$ \\
\hline \multirow[t]{2}{*}{ Years Squared } & -0.0001 & -0.0001 & -0.0001 \\
\hline & $(0.0004)$ & $(0.0004)$ & $(0.0004)$ \\
\hline \multirow[t]{2}{*}{ Commerce } & 0.092 & 0.495 & 1.013 \\
\hline & $(0.186)$ & $(0.228)^{* * *}$ & $(0.237)^{* * *}$ \\
\hline \multirow[t]{2}{*}{ Creative Arts } & 0.640 & 0.336 & 0.337 \\
\hline & $(0.237)^{* * *}$ & $(0.331)$ & $(0.348)$ \\
\hline \multirow[t]{2}{*}{ Education } & 0.473 & 0.011 & 0.242 \\
\hline & $(0.208)^{* *}$ & $(0.180)$ & $(0.193)$ \\
\hline \multirow[t]{2}{*}{ Engineering } & 0.208 & 0.560 & 0.776 \\
\hline & $(0.228)$ & $(0.232)^{* * *}$ & $(0.241)^{* * *}$ \\
\hline \multirow[t]{2}{*}{ Health Science } & 0.468 & 0.442 & 0.518 \\
\hline & $(0.196)^{* * *}$ & $(0.205)^{* *}$ & $(0.208)^{* * *}$ \\
\hline \multirow[t]{2}{*}{ Informatics } & 0.260 & 0.133 & 0.420 \\
\hline & $(0.193)$ & $(0.217)$ & $(0.230)^{*}$ \\
\hline \multirow[t]{2}{*}{ Law } & 0.848 & 0.401 & 0.621 \\
\hline & $(0.234)^{* * *}$ & $(0.189 * * *$ & $(0.200)^{* * *}$ \\
\hline \multirow[t]{2}{*}{ Science } & 0.180 & 0.177 & 0.346 \\
\hline & $(0.203)$ & $(0.184)$ & $(0.197)^{*}$ \\
\hline \multirow[t]{2}{*}{ Graduate School of Medicine } & 0.664 & 0.737 & 0.936 \\
\hline & $(0.223)^{* * *}$ & $(0.230)^{* * *}$ & $(0.236)^{* * *}$ \\
\hline \multirow[t]{2}{*}{ Sydney Business School } & 0.427 & 0.100 & 0.439 \\
\hline & $(0.335)$ & $(0.197)$ & $(0.207)^{* *}$ \\
\hline \multirow[t]{2}{*}{ Journal Articles } & 0.011 & 0.039 & 0.012 \\
\hline & $(0.003)^{* * *}$ & $(0.066)^{* * *}$ & $(0.005)^{* * *}$ \\
\hline \multirow[t]{2}{*}{ Books and Book Chapters } & 0.056 & 0.050 & 0.136 \\
\hline & $(0.014)^{* * *}$ & $(0.022)^{* *}$ & $(0.027)^{* * *}$ \\
\hline \multirow[t]{2}{*}{ Conference Proceedings } & 0.002 & 0.004 & 0.004 \\
\hline & $(0.001)$ & $(0.0049$ & $(0.003)$ \\
\hline \multirow[t]{2}{*}{ Competitive Grants } & 0.189 & 0.417 & 0.195 \\
\hline & $(0.044)^{* * *}$ & $(0.142)^{* * *}$ & $(0.052)^{* * *}$ \\
\hline \multirow[t]{2}{*}{ Other Grants } & 0.004 & 0.004 & 0.010 \\
\hline & $(0.004)$ & $(0.009)$ & $(0.007)$ \\
\hline Pseudo R2 & 0.26 & 0.24 & 0.25 \\
\hline Number of Observations & 688 & 688 & 687 \\
\hline
\end{tabular}

Standard errors reported within parenthesis.

$*$, **, ***, significant at the $10 \%, 5 \%$ and $1 \%$ levels respectively. 
Table 7: Marginal Probabilities for 2000-2010

\begin{tabular}{|c|c|c|c|c|c|}
\hline & (1) & (2) & (3) & (4) & (5) \\
\hline Variable & $\operatorname{Pr}[y=1]$ & $\operatorname{Pr}[y=2]$ & $\operatorname{Pr}[y=3]$ & $\operatorname{Pr}[y=4]$ & $\operatorname{Pr}[y=4]$ \\
\hline & $\begin{array}{l}\text { Associate } \\
\text { Lecturer }\end{array}$ & Lecturer & $\begin{array}{l}\text { Senior } \\
\text { Lecturer }\end{array}$ & Ass. Prof & Professor \\
\hline Male & $\begin{array}{l}-0.003 \\
(0.001)^{* *}\end{array}$ & $\begin{array}{l}-0.145 \\
(0.033) * * *\end{array}$ & $\begin{array}{l}0.008 \\
(0.009)\end{array}$ & $\begin{array}{l}0.087 \\
(0.020) * * *\end{array}$ & $\begin{array}{l}0.052 \\
(0.012) * * *\end{array}$ \\
\hline Full Time & $\begin{array}{l}0.001 \\
(0.0007) *\end{array}$ & $\begin{array}{l}0.081 \\
(0.041)^{* *}\end{array}$ & $\begin{array}{l}0.008 \\
(0.001)\end{array}$ & $\begin{array}{l}-0.052 \\
(0.058) *\end{array}$ & $\begin{array}{l}-0.038 \\
(0.024)\end{array}$ \\
\hline $\mathrm{PhD}$ & $\begin{array}{l}-0.042 \\
(0.012)^{* * *}\end{array}$ & $\begin{array}{l}0.481 \\
(0.043) * * *\end{array}$ & $\begin{array}{l}0.180 \\
(0.035)^{* * *}\end{array}$ & $\begin{array}{l}0.233 \\
(0.021)^{* * *}\end{array}$ & $\begin{array}{l}0.110 \\
(0.013) * * *\end{array}$ \\
\hline Years & $\begin{array}{l}-0.0003 \\
(0.0001)^{* *}\end{array}$ & $\begin{array}{l}-0.015 \\
(0.004)^{* * *}\end{array}$ & $\begin{array}{l}0.0001 \\
(0.0009) \\
\end{array}$ & $\begin{array}{l}0.009 \\
(0.003)^{* * *}\end{array}$ & $\begin{array}{l}0.006 \\
(0.001)^{* * *}\end{array}$ \\
\hline Years Squared & $\begin{array}{c}0.000 \\
0.0000\end{array}$ & $\begin{array}{l}0.00004 \\
(0.0001)\end{array}$ & $\begin{array}{l}-0.000 \\
(0.000)\end{array}$ & $\begin{array}{l}-0.00002 \\
(0.00009)\end{array}$ & $\begin{array}{l}-0.00001 \\
(0.00006)\end{array}$ \\
\hline Commerce & $\begin{array}{l}-0.0005 \\
(0.001)\end{array}$ & $\begin{array}{l}-0.032 \\
(0.059)\end{array}$ & $\begin{array}{l}-0.0009 \\
(0.004)\end{array}$ & $\begin{array}{l}0.019 \\
(0.038)\end{array}$ & $\begin{array}{l}0.012 \\
(0.026)\end{array}$ \\
\hline Creative Arts & $\begin{array}{l}-0.002 \\
(0.0009) * *\end{array}$ & $\begin{array}{l}-0.174 \\
(0.050) * * *\end{array}$ & $\begin{array}{l}-0.063 \\
(0.045)\end{array}$ & $\begin{array}{l}0.116 \\
(0.033) * * *\end{array}$ & $\begin{array}{l}0.123 \\
(0.062)^{* *}\end{array}$ \\
\hline Education & $\begin{array}{l}-0.001 \\
(0.0008)^{* *}\end{array}$ & $\begin{array}{l}-0.138 \\
(0.052)^{* * *}\end{array}$ & $\begin{array}{l}-0.033 \\
(0.030)\end{array}$ & $\begin{array}{l}0.092 \\
(0.036) * * *\end{array}$ & $\begin{array}{l}0.082 \\
(0.046)^{*}\end{array}$ \\
\hline Engineering & $\begin{array}{l}-0.001 \\
(0.001) \\
\end{array}$ & $\begin{array}{l}-0.066 \\
(0.068) * * *\end{array}$ & $\begin{array}{l}-0.006 \\
(0.014) \\
\end{array}$ & $\begin{array}{l}0.042 \\
(0.045) \\
\end{array}$ & $\begin{array}{l}0.030 \\
(0.038)\end{array}$ \\
\hline Health Science & $\begin{array}{l}-0.002 \\
(0.0009) * *\end{array}$ & $\begin{array}{l}-0.139 \\
(0.051)^{* * *}\end{array}$ & $\begin{array}{l}-0.028 \\
(0.025)\end{array}$ & $\begin{array}{l}0.092 \\
(0.035) * * *\end{array}$ & $\begin{array}{l}0.078 \\
(0.041)^{* *}\end{array}$ \\
\hline Informatics & $\begin{array}{l}-0.001 \\
(0.0009)\end{array}$ & $\begin{array}{l}-0.081 \\
(0.057) \\
\end{array}$ & $\begin{array}{l}-0.008 \\
(0.014) \\
\end{array}$ & $\begin{array}{l}0.052 \\
(0.038) \\
\end{array}$ & $\begin{array}{l}0.039 \\
(0.033)\end{array}$ \\
\hline Law & $\begin{array}{l}-0.002 \\
(0.001)^{* *}\end{array}$ & $\begin{array}{l}-0.213 \\
(0.010)^{* * *}\end{array}$ & $\begin{array}{l}-0.106 \\
(0.053)^{* *}\end{array}$ & $\begin{array}{l}0.139 \\
(0.023)^{* * *}\end{array}$ & $\begin{array}{l}0.182 \\
(0.071)^{* * *}\end{array}$ \\
\hline Science & $\begin{array}{l}-0.0009 \\
(0.0009) \\
\end{array}$ & $\begin{array}{l}-0.057 \\
(0.062) \\
\end{array}$ & $\begin{array}{l}-0.004 \\
(0.010)\end{array}$ & $\begin{array}{l}0.036 \\
(0.041) \\
\end{array}$ & $\begin{array}{l}0.026 \\
(0.032) \\
\end{array}$ \\
\hline $\begin{array}{l}\text { Graduate School of } \\
\text { Medicine }\end{array}$ & $\begin{array}{l}-0.002 \\
(0.0009) * *\end{array}$ & $\begin{array}{l}-0.180 \\
(0.048)^{* * *}\end{array}$ & $\begin{array}{l}-0.066 \\
(0.044) \\
\end{array}$ & $\begin{array}{l}0.120 \\
(0.032)^{* * *}\end{array}$ & $\begin{array}{l}0.129 \\
(0.061)^{* *}\end{array}$ \\
\hline $\begin{array}{l}\text { Sydney Business } \\
\text { School }\end{array}$ & $\begin{array}{l}-0.001 \\
(0.0009) * *\end{array}$ & $\begin{array}{l}-0.124 \\
(0.084)\end{array}$ & $\begin{array}{l}-0.034 \\
(0.019)\end{array}$ & $\begin{array}{l}0.083 \\
(0.057)\end{array}$ & $\begin{array}{l}0.074 \\
(0.074)\end{array}$ \\
\hline Journal Articles & $\begin{array}{l}-0.00007 \\
(0.00002)^{* *}\end{array}$ & $\begin{array}{l}-0.003 \\
(0.001)^{* * *}\end{array}$ & $\begin{array}{l}0.00002 \\
(0.0002) \\
\end{array}$ & $\begin{array}{l}0.002 \\
(0.0006)^{* * *}\end{array}$ & $\begin{array}{l}0.001 \\
(0.0004) * * *\end{array}$ \\
\hline $\begin{array}{l}\text { Books and Book } \\
\text { Chapters }\end{array}$ & $\begin{array}{l}-0.0003 \\
(0.0001)^{* *}\end{array}$ & $\begin{array}{l}-0.018 \\
(0.004) * * *\end{array}$ & $\begin{array}{l}0.0001 \\
(0.001)\end{array}$ & $\begin{array}{l}0.011 \\
(0.003) * * *\end{array}$ & $\begin{array}{l}0.007 \\
(0.001)^{* * *}\end{array}$ \\
\hline $\begin{array}{l}\text { Conference } \\
\text { Proceedings }\end{array}$ & $\begin{array}{l}-0.00001 \\
(0.00001)\end{array}$ & $\begin{array}{l}-0.0007 \\
(0.0005)\end{array}$ & $\begin{array}{l}0.000 \\
(0.000)\end{array}$ & $\begin{array}{l}0.0004 \\
(0.0003)\end{array}$ & $\begin{array}{l}0.0002 \\
(0.0002)\end{array}$ \\
\hline Competitive Grants & $\begin{array}{l}-0.001 \\
(0.0005) * *\end{array}$ & $\begin{array}{l}-0.062 \\
(0.014) * * *\end{array}$ & $\begin{array}{l}0.0004 \\
(0.003)\end{array}$ & $\begin{array}{l}0.038 \\
(0.009) * * *\end{array}$ & $\begin{array}{l}0.024 \\
(0.006) * * *\end{array}$ \\
\hline Other Grants & $\begin{array}{l}-0.00002 \\
(0.00002)\end{array}$ & $\begin{array}{l}-0.001 \\
(0.001)\end{array}$ & $\begin{array}{l}0.00001 \\
(0.00009)\end{array}$ & $\begin{array}{l}0.0009 \\
(0.0008)\end{array}$ & $\begin{array}{l}0.0005 \\
(0.0005)\end{array}$ \\
\hline Base Probability & 0.0021 & 0.2829 & 0.4343 & 0.2130 & 0.0676 \\
\hline
\end{tabular}

$*, * *, * *$, significant at the $10 \%, 5 \%$ and $1 \%$ levels respectively. 
Table 8: Dependent Variable Rank $(\mathrm{Y}=1,2,3,4,5)$

\begin{tabular}{|c|c|c|c|}
\hline & (1) & (2) & (3) \\
\hline & $2000-2010$ & $2000-2005$ & $2006-2010$ \\
\hline Variable & Coefficient Estimate & Coefficient Estimate & Coefficient Estimate \\
\hline Male & $\begin{array}{l}0.434 \\
(0.097) * * *\end{array}$ & $\begin{array}{l}0.392 \\
(0.097)^{* * *}\end{array}$ & $\begin{array}{l}0.426 \\
(0.097)^{* * *}\end{array}$ \\
\hline Full Time & $\begin{array}{l}0.255 \\
(0.142)^{*}\end{array}$ & $\begin{array}{l}0.202 \\
(0.142) \\
\end{array}$ & $\begin{array}{l}0.218 \\
(0.139) \\
\end{array}$ \\
\hline $\mathrm{PhD}$ & $\begin{array}{l}1.444 \\
(0.145)^{* * *}\end{array}$ & $\begin{array}{l}1.479 \\
(0.142)^{* * *}\end{array}$ & $\begin{array}{l}1.437 \\
(0.145)^{* * *}\end{array}$ \\
\hline Years & $\begin{array}{l}0.046 \\
(0.014)^{* * *}\end{array}$ & $\begin{array}{l}0.045 \\
(0.014) * * * \\
\end{array}$ & $\begin{array}{l}0.048 \\
(0.014)^{* * *} \\
\end{array}$ \\
\hline Years Squared & $\begin{array}{l}-0.0001 \\
(0.0004) \\
\end{array}$ & $\begin{array}{l}-0.0001 \\
(0.0004) \\
\end{array}$ & $\begin{array}{l}-0.00007 \\
(0.0004) \\
\end{array}$ \\
\hline Commerce & $\begin{array}{l}0.086 \\
(0.188)\end{array}$ & $\begin{array}{l}0.585 \\
(0.230)^{* * *}\end{array}$ & $\begin{array}{l}1.016 \\
(0.237)^{* * *}\end{array}$ \\
\hline Creative Arts & $\begin{array}{l}0.647 \\
(0.238)^{* * *}\end{array}$ & $\begin{array}{l}0.443 \\
(0.334) \\
\end{array}$ & $\begin{array}{l}0.280 \\
(0.350) \\
\end{array}$ \\
\hline Education & $\begin{array}{l}0.461 \\
(0.208) * * \\
\end{array}$ & $\begin{array}{l}0.074 \\
(0.181) \\
\end{array}$ & $\begin{array}{l}0.220 \\
(0.195) \\
\end{array}$ \\
\hline Engineering & $\begin{array}{l}0.138 \\
(0.232) \\
\end{array}$ & $\begin{array}{l}0.587 \\
(0.233)^{* * *}\end{array}$ & $\begin{array}{l}0.828 \\
(0.243)^{* * *}\end{array}$ \\
\hline Health Science & $\begin{array}{c}0.452 \\
(0.199)^{* *}\end{array}$ & $\begin{array}{l}0.477 \\
(0.206)^{* *}\end{array}$ & $\begin{array}{l}0.504 \\
(0.209)^{* * *}\end{array}$ \\
\hline Informatics & $\begin{array}{l}0.225 \\
(0.195) \\
\end{array}$ & $\begin{array}{l}0.162 \\
(0.220) \\
\end{array}$ & $\begin{array}{l}0.362 \\
(0.233) \\
\end{array}$ \\
\hline Law & $\begin{array}{l}0.833 \\
(0.235)^{* * *} \\
\end{array}$ & $\begin{array}{l}0.479 \\
(0.191)^{* * *} \\
\end{array}$ & $\begin{array}{l}0.592 \\
(0.203)^{* * *} \\
\end{array}$ \\
\hline Science & $\begin{array}{l}0.104 \\
(0.210)\end{array}$ & $\begin{array}{l}0.218 \\
(0.186)\end{array}$ & $\begin{array}{l}0.312 \\
(0.198)\end{array}$ \\
\hline Graduate School of Medicine & $\begin{array}{l}0.669 \\
(0.234)^{* * *}\end{array}$ & $\begin{array}{l}0.779 \\
(0.231)^{* * *}\end{array}$ & $\begin{array}{l}0.945 \\
(0.237)^{* * *}\end{array}$ \\
\hline Sydney Business School & $\begin{array}{l}0.404 \\
(0.338)\end{array}$ & $\begin{array}{l}0.108 \\
(0.204)\end{array}$ & $\begin{array}{l}0.379 \\
(0.212)^{*}\end{array}$ \\
\hline \multicolumn{4}{|l|}{ Journal Articles } \\
\hline $\mathrm{A}^{*}$ & $\begin{array}{l}0.045 \\
(0.018)^{* * *}\end{array}$ & $\begin{array}{l}0.058 \\
(0.032) * \\
\end{array}$ & $\begin{array}{l}0.066 \\
(0.026)^{* * *}\end{array}$ \\
\hline $\mathrm{A}$ & $\begin{array}{l}0.012 \\
(0.012)\end{array}$ & $\begin{array}{l}0.090 \\
(0.027)^{* * *}\end{array}$ & $\begin{array}{l}0.005 \\
(0.017)\end{array}$ \\
\hline B & $\begin{array}{l}0.004 \\
(0.008) \\
\end{array}$ & $\begin{array}{l}0.044 \\
(0.022)^{* *}\end{array}$ & $\begin{array}{l}0.014 \\
(0.014) \\
\end{array}$ \\
\hline $\mathrm{C}$ & $\begin{array}{l}0.022 \\
(0.013)^{*}\end{array}$ & $\begin{array}{l}0.011 \\
(0.024)\end{array}$ & $\begin{array}{l}0.051 \\
(0.022)^{* *}\end{array}$ \\
\hline Other & $\begin{array}{l}0.009 \\
(0.012) \\
\end{array}$ & $\begin{array}{l}0.101 \\
(0.025)^{* * *}\end{array}$ & $\begin{array}{l}-0.013 \\
(0.017) \\
\end{array}$ \\
\hline Books and Book Chapters & $\begin{array}{l}0.057 \\
(0.014)^{* * *}\end{array}$ & $\begin{array}{l}0.044 \\
(0.022)^{* *}\end{array}$ & $\begin{array}{l}0.145 \\
(0.028)^{* * *}\end{array}$ \\
\hline Conference Proceedings & $\begin{array}{l}0.002 \\
(0.001)\end{array}$ & $\begin{array}{l}0.005 \\
(0.003)^{*}\end{array}$ & $\begin{array}{l}0.004 \\
(0.003)\end{array}$ \\
\hline Competitive Grants & $\begin{array}{l}0.181 \\
(0.047)^{* * *}\end{array}$ & $\begin{array}{l}0.417 \\
(0.143)^{* * *}\end{array}$ & $\begin{array}{l}0.084 \\
(0.055) * * *\end{array}$ \\
\hline Other Grants & $\begin{array}{l}0.005 \\
(0.004)\end{array}$ & $\begin{array}{l}-0.004 \\
(0.009) \\
\end{array}$ & $\begin{array}{l}0.013 \\
(0.007)^{*}\end{array}$ \\
\hline Pseudo R2 & 0.26 & 0.25 & 0.26 \\
\hline Number of Observations & 688 & 688 & 687 \\
\hline
\end{tabular}

Standard errors reported within parenthesis.

$*, * *, * * *$, significant at the $10 \%, 5 \%$ and $1 \%$ levels respectively. 
Table 9: Oaxaca-Blinder Decomposition

\begin{tabular}{|c|c|c|c|c|}
\hline (1) & (2) & (3) & (4) & (5) \\
\hline $\begin{array}{l}\text { Accounted for } \\
\text { by differences } \\
\text { in }\end{array}$ & $\begin{array}{l}\text { Predicted female } \\
\text { with male } \\
\text { endowments and } \\
\text { coefficients }\end{array}$ & $\%$ of Gap & $\begin{array}{l}\text { Predicted male } \\
\text { with female } \\
\text { endowments } \\
\text { and } \\
\text { coefficients }\end{array}$ & $\%$ of Gap \\
\hline Endowments & $\begin{array}{l}0.477 \\
(0.081)^{* * *}\end{array}$ & $59.40 \%$ & $\begin{array}{l}-0.330 \\
(0.063) * * *\end{array}$ & $64.71 \%$ \\
\hline Coefficients & $\begin{array}{l}0.326 \\
(0.070) * * *\end{array}$ & $40.60 \%$ & $\begin{array}{l}-0.180 \\
(0.076)^{* *}\end{array}$ & $35.29 \%$ \\
\hline
\end{tabular}

